\title{
Ecofeminist Theologies Challenge Domination
}

\author{
Ioanna Sahinidou \\ Greek Evangelical Church, Synodic Committee: Sanctity of Life, Ecology, Athens, Greece \\ Email: ioansahi@otenet.gr
}

How to cite this paper: Sahinidou, I. (2017). Ecofeminist Theologies Challenge Domination. Open Journal of Philosophy, 7, 249-259. https://doi.org/10.4236/ojpp.2017.73015

Received: April 22, 2017

Accepted: July 14, 2017

Published: July 17, 2017

Copyright (c) 2017 by author and Scientific Research Publishing Inc. This work is licensed under the Creative Commons Attribution International License (CC BY 4.0).

http://creativecommons.org/licenses/by/4.0/

\begin{abstract}
Because power and control offer a sense of superiority to the ruler, both women and nature are dominated. In analyzing domination and its various forms, all share certain features: 1) A radical exclusion, making the "other" known as both inferior and separate. 2) Homogenization differences and diversity within the otherness is disregarded and domination appears as natural. 3) Women and nature act as backgrounds to the main, masculine activities; slaves exist as background to the dominant group. 4) Incorporation means to identify the other in relation to man as central. 5) Instrumentalism means that social worth is derived instrumentally according to the desires of the ruler. This substructure provides an analytical tool. Ecofeminist Theology seeks a theology beyond dualisms. ${ }^{1}$
\end{abstract}

\section{Keywords}

Domination, Soul-Body-Nepes, Human Beings-Nature, Men-Women

\section{Introduction}

Domination is rooted in a common ideology based on the control of reason over nature, and on the separation of the spiritual from the material world, an idea based in turn on the separation of our beings into soul and body. Ecofeminists see domination as a core phenomenon and the ideological/material root of the woman/nature nexus (Eaton, 2005: p. 59). The theoretical work brings to consciousness for the past as basic to know the present. Regardless of its origins, patriarchy's era and relevance must end (Eaton, 2005: p. 69). To reconsider human persons as ecological persons is to rethink the dualistic philosophy on which western cultures were built. Ecofeminist theologians use new cosmologies and anthropologies in seeking a theology beyond dualisms. They seek a cosmology that embraces a liberationist methodology, an eco-social justice view, a sacredness and integrity of creation, a holiness of body that includes sexuality and 
sensuality, and a spirituality that exalts God's transcendence/immanence.

Dualisms correspond to gender, class, race, and nature vs. human domination. We are trapped within our cultures of comparison, competition, and antagonism. Perhaps the most destructive dualism was the mechanistic worldview, where the earth was seen as a machine, God as its designer, and humans as created to run the machine for their use (Habel, 2000: p. 41). Dualisms result in distorted relationships with God, within our selves, with other humans and the rest of creation. I address the eco-social problem as a split in our being and the way out of "split selves" towards "whole selves".

One of my motivations for focusing on perichoresis relations as the coinherence in Christ of the human and divine natures is that it illustrates the relationship between God, the Creator and the creation. My goal is for a healed relationship among humans and between humans, the earth and its beings, which will ultimately lead to a holistic perichoresis consciousness and a culture opposing domination-systems as well as the exploitation of nature. The eco-theological problem is one of humanity being in non-perichoresis relationship within itself, God, and the rest of creation. To heal this rift is a process of cultivating perichoretic relations between them, in Christ. In this article I trace the development of the concept of "perichoresis" as a preliminary to study its promise, potential, and implications for ecotheology.

\section{Ecofeminist Theologies}

Ecofeminist theorists Karen Waren and Val Plumwood frame ecofeminism as a wave of feminism (Plumwood, 1993: p. 39), including many voices and views, with a wide range of analyses and actions of links between women and nature, which resists inter-human, human-earth patriarchal relations. For ecofeminism social structures, worldviews, domination and oppression of women are interconnected. The theoretical work brings to consciousness the past as basis to knowing the present; it makes us aware of the values hidden in worldviews. To know patriarchy, domination, the oppression of nature and their interconnections is to open the possibility of dismantling them by denunciation (Eaton, 2005: p. 61). The cases are studied in terms of their ecological impact and correlations to issues of ethnicity, class, and gender. Ecofeminism is the history of women-nature links, a lens through which many disciplines can be refocused, a nexus within ecosocial movements; a way to see how women's concerns link to the eco-crisis drawing reflections from ethics, philosophy, sociology, politics, religion, environmental economy, and women's studies.

Ecofeminist theory expresses the conceptual, symbolic, cultural links between women and nature. Cultural historian Rosemary Radford Ruether traces the symbolic connections of domination of women and nature. As a result of anthropological studies comes the idea that to identify women with nature and to monopolize the definition of culture for males is both ancient and widespread. A key element of this identification lies in the early human social patterns in which women's reproductive role was tied to making women the primary productive 
and maintenance workers. Women did the work related to child care, food production/preparation, clothing production, clean up, waste disposal. Males were involved in work such as hunting animals, war, and clearing fields.

The work of women as the primary producers-reproducers was perhaps thought to be very important. This consciousness disappeared under growing male power to define the culture for the society, socializing both males and females into a male-defined view. The work of women to maintain the basis of life is defined as inferior realm, from the view of the male monopoly of culture. The material world seen as separated from males symbolically was linked with women. The earth from which animal and plant life arises was linked with the bodies of women, from which babies are born. The development of plough agriculture and human slavery was dominated by men. Land was inherited through the male line, rather than communal land holding, and matrilineal descent was that of gathering and gardening societies.

Enslavement through military conquest took the form of killing men and enslaving women and their children for labour and sexual service. The men of the family were the heads and their women belonged to a higher type of slave who ruled over a lower type drawn from conquered people. In patriarchal law, possession of women, slaves, animals and land were linked together, owned by male family heads as ruling class (Ruether, 1993: pp. 13-20). Looking at the stories of the Ancient Near Eastern, Hebrew; Greek and early Christian cultures, we see a symbolization of women and nature as spheres to be conquered, ruled over and rejected (Ruether, 1993: pp. 13-20). The division of labour meant that women's work was for the basic sustenance of life (=nature) as a private home-responsibility, in contrast with male public work for government and civil affairs (=culture) (Grey, 2004: pp. 153-155). Social analysts argue that the basic division of labour is that of the "public wage labour" of men and the "private housework" of women. The phrase "without women, you cannot make a state" means that the women of a state must be colonized as housewives to maintain the state (Mies, 1993: pp. 120-121). The structural analysis of work as being only outside home makes the economic basis of women's reproductive work invisible.

Since women are productive and reproductive, the care for the home must be taken into the struggle for just structural relations between men and women. Man as gender-blind concept, was uncovered in anthropology, sociology, psychology, philosophy and the sciences. Feminist theologies depend on analyses of secular feminism and are critical of the consciousness and cultural patterns that hold domination over women, for reforming society and reconstructing theology. Feminist theology uncovers practices holding injustices imposed on women, denying their full humanity and trying to create a liberating theology as transformation praxis.

Analysis of theological frames assisting in women's and nature's oppression is the basis for ecofeminist theology. Today, nature comes packaged and commodified. Ecofeminists claim that the logic of domination supports the shared oppression of women and nature (Grey, 2004: p. 155). Gerda Lerner argues that pa- 
triarchy emerged due to the realization that power over and domination is an effective weapon (Lerner, 1988: pp. 119-132). To know ecofeminist spiritualities philosophically means to consider patriarchy as a dysfunctional social system rooted in patriarchal conceptual frameworks. Ecofeministm challenges patriarchy as a belief system, replacing it with non-dominating beliefs, values, behaviours and relations between humans and non human nature. Philosophical attention to ecofeminist spiritualities explains and realizes the role that the spiritual experiences of women play in deconstructing patriarchy. The idea that ecofeminist spiritualities support ecofeminist strategies to empower women, while challenging patriarchal structures and practices, captures the creative ways women are acting to improve both their own lives and the lives of others (Warren, 1993: pp. 119-132).

\section{Dualisms within the Human Person: Soul-Body}

If human society needs to find a home in nature, then the human soul needs a home in the bodily existence of each human being (Moltmann, 1985: pp. 47-49). To speak of body and psyche, or of spirit and matter includes any dimension of a being, existing in, for, from and with all other dimensions of its being, each dimension interrelated in its differentiation with all its other dimensions. A person thinks with the mind, body, feelings, ideas, intentions, decisions linked with bodily organs. The primacy of soul is alien to such a knowing; soul and body exist as a whole being. We are all "body", "psyche", "soul".

Already from 3000 BC the Egyptians were discussing the existence of $\psi v x \eta$. $\Psi v \times \eta$-psyche was known as the source of life of the cosmos. For ancient Greeks, the parts of the body were agents of intellectual and spiritual functions. There was no master-concept of the soul. $\Psi v x \eta$ became the term for the newly found master-concept in the $6^{\text {th }}$ century $\mathrm{BC}$, connected with the belief in retribution in the hereafter, widespread from the $7^{\text {th }}$ century onwards. $\Psi v x \eta$ guaranteed the continuity of life in this world and in the hereafter.

For Plato, the demiurge first created $\psi v \times \dot{\eta}$, so that $\psi v \times \eta \dot{~ w o u l d ~ r u l e ~ o v e r ~ t h e ~}$

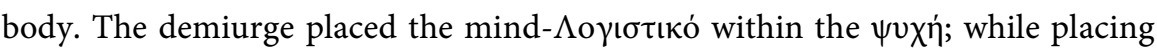

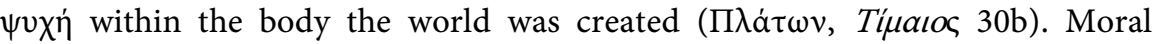
struggle is a flight from the world of sense, an approach to intelligible being-God. As the soul's pre-eminent part belongs to transcendent being, it is pre-existent and immortal. The rational sphere of the soul is human; the impulsive sphere humans share with animals; the vegetative sphere they share with both animals and plants.

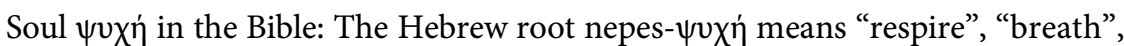
"life"; "self"; "person"; "desire"; to be refreshed (Ex. 23:12, 31:17, 2 Sam 16:14) in connection with the Sabbath rest which consists of rest and activity; breathing denotes the life always threatened and re-won in the cosmos. Nepes denotes the vital force, giving priority to the anthropological wording. (Gen 2.7) expresses this idea when it calls a total human being, a living being. Nepes does not exist apart from the body: (Gen 27.25). For Hebrew anthropology, the totality can be 
concentrated in a part. The collectivist element never restricts in Judaism the significance of the individual who is quickened by a unitary life. The metaphor of nepes as the substructure of the anthropological wording shows life as breathing exercise. If God ceases to breath into humans, life stops for them (Jacob, 1999: Friedrich (ed.), pp. 617-631).

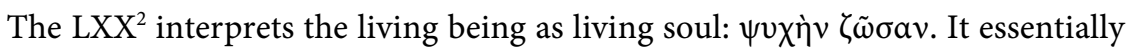
means "life". The relations of breath and life take a semantic step when nepes denotes the living being itself (Lev. 4:2, Josh 11:14) in referring to the self (Ps 7:2[3], Lev 26:11.) In the NT, soul is the seat of life or life itself (Mark 8:36-8, Mathieu 10.39, Luke 17.33, John 12.25). The soul as it is spoken of in the NT goes beyond Greek thought, as seat of the religious life and of a person's relationship to God (Dihle, 1999: Kittel \& Friedrich (eds.), pp. 637-645). For Apostle Paul, a human being is a psychosomatic unity with integrated rational, emotional and physical functions. Scholars now insist that Paul's anthropology must be seen in light of his own historical and cultural context, since Paul opposed the non Jewish teaching. The influences upon him were Jesus, the OT and Palestinian Judaism. $\Psi v X \eta \dot{\eta}$ is the life of the whole person (Gen 2.27. 6.). Rooted in the $\mathrm{OT}$ are Paul's anthropological term á $v \theta \rho \omega \pi$ oc-human being (1 Cor. 12. 12-3) to define corporeality (Chamlin, 1993: pp. 765-70.).

In the field of medical sciences, the term "psychosomatic diseases", was used to express the interrelatedness of psyche and body. According to the psychiatrist George Engel, psychiatric and somatic diseases, were two sides of the same coin because of the influence of biological, psychological, and psychosocial factors. Thus, all diseases were thought of as psychosomatic. Yet, the diagnosis of a disease as psychosomatic indirectly reinforces the dualistic notion that separates psyche and body. In the latest classifying systems of psychiatry, any disease must

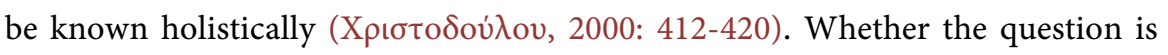
who we are or what we are to become, the idea of "soul" conveys a sense of being as God-given, morally freighted in our selves, transcending all natural categories (Miller, 1993: pp. 507-510).

\section{Ecofeminist Reflections on $\Psi v \chi \eta$ '}

Theology needs to retrieve the idea of soul in Homer where there is no masterconcept of soul, and dissociate the anthropological LXX use of "soul" from Platonic dualisms. It must consider the biblical tradition where humans are seen as related to their own selves, an idea found in the OT usage of nepes. Feminists must retrieve the NT meaning of soul as a person's relationship to God and the

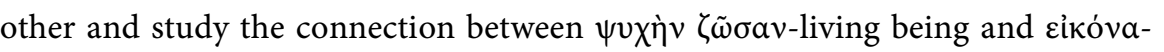
image of God leading to a relational creation connected to the Creator who breathes into human nostrils the breath of life. The image of God, where both men and women are included, offers justice to women, while Plato discriminates on the basis of soul-body.

\footnotetext{
${ }^{2}$ The Septuagint (or "LXX", or "Greek Old Testament") is a translation of the Hebrew Bible and some related texts into Greek begun in the late $3^{\text {rd }}$ century BCE. The Septuagint is quoted by the New Testament (particularly by St. Paul) and by the Apostolic Fathers.
} 


\section{Dualisms between Human Beings}

\subsection{Liberation Theologies}

I situate feminist theology within the framework of liberation theologies. In any suffering group of people, discriminated because of race, ethnicity, or religion, women suffer worse for they are thought to be inferior to men. Liberation theology emerged in Latin America in the 1970's. Oppressive experiences of vulnerability or marginalization led to a reflection on the Christian tradition. Liberation theology stressed the need for dialogue between Christian tradition, social theory, and the insights of the marginalized poor, leading to action for change. Its roots are in the Christian emphasis on the commitment to the poor and to one's neighbour as a context to know God (Rowland (ed.), 1999: pp. xiii-xv). The challenge in Latin America is to search for God amidst a situation created by injustice and poverty; exploited races and classes; excluded cultures, and often women suffering discrimination.

Scripture condemns structural injustice and exploitation: "Yahweh has liberated the poor from the hands of evil men" (Jeremiah 20.13). The outpouring love of God needs acts that become the praxis of love towards the weak among our neighbours. A Christian community that provides the testimony to a life victorious over death is crucial in a continent suffering from premature and unjust death while fighting against oppression. Liberation theology makes present in the world of oppression, injustice and death, the Word of life (Gutierrez, 1999: pp. 36-37). The liberation theology movement sprang from Gutierrez's 1970s study in response to criticisms made (Rowland (ed.), 1999: p. 8).

Black theology emerged in the late 1960s, exploring ways in which AfricanAmericans reworked their faith in the context of their experience of slavery, as a critical search for a historical, black Christian faith that wrestled with issues of racial justice and liberation. The challenge comes both from the past realities of slavery and the present reality of racism; the meaning of Jesus' humanity can be construed within the context of the message of liberation (Antonio, 2002: Rowland (ed.), pp. 63, 83). Feminist, womanist, ${ }^{3}$ and mujerista ${ }^{4}$ theologies make the liberation of women central to the theological task, sharing liberation hermeneutic committed to identity. They began by critically confronting the social, ecclesial and theological structures. Liberation theologians built an interpretive paradigm for praxis having as a research view the critical relationship of theory and practice, biblical texts, and liberation movements. This paradigm generates new models that can evaluate biblical traditions and their function in history (Fiorenza, 2002: p. 63).

\subsection{Gender as Hermeneutical Tool to Overcome Dualisms}

Feminists consider gender as a tool to point out the deficiency of theories that use biology to explain the societal inequality between men and women. To speak of gender means to speak about a way of existing based on both the biological character of our being and on our character that involve matters of culture, his-

${ }^{3}$ Womanist refers to African American women's idea of the experiences of black feminists.

${ }^{4}$ Mujerista theologies work from the lived experience of the US Latinas. 
tory, society, ideology and religion. To refer to gender is to speak about male and female in relation to social and cultural output, in knowing and learning behaviour in the practicing of those behaviours. It means to introduce a certain way of living, proper to each sex, result of a complex web of cultural and social relationships, and to influence the relationships of men and women lived in private or in public. Gender, wider and deeper than biological sex, nests in this dynamic of relationships.

The interrelatedness and interdependence of all the beings in the cosmos, uncovers the dualism: soul/body, creating a theological anthropology that becomes the reality of all. As a human cosmic condition beyond consciousness, as a religious experience that gives up anthropocentrism, interrelatedness knows the world as our widest cosmic reality. Cosmic differentiation is demanded by multiform relatedness: any being is a unique cosmic manifestation. We question the autonomy of the human person for its individualistic limits, and any person's dependence on all else.

God's image is not based on gender norms, ideas of dominion over people and nature, or on the mind /body split. A critical feminist hermeneutics of liberation develops a dialectical mode of biblical exegesis that asserts that all forms of dominion are sinful. This hermeneutic also gives justice to women's experiences of the Bible as source of empowerment in our struggle for liberation (Fiorenza, 2002: pp. 63). Schüssler Fiorenza discusses the challenge of feminist biblical exegesis that always claims the right of women to interpret experience tradition, and religion from their own perspective. Equality and freedom cannot be realized if women's voices are not raised, heard, and considered by all in the struggle for liberation regardless of sex, class, nationality, race or religion. Fiorenza emphasizes the feminist struggle for the discipleship of equals (Fiorenza, 2002: pp. 178-179).

A hermeneutics of suspicion must test both the original biblical text and the contemporary translations for linguistic sexism. Some guidelines to considering whether sexist language and framing exist are: Does sexist language create the linguistic invisibility or marginality of women? Does it describe women as dependent on men? Does it characterize women in stereotypical roles (Fiorenza, 2002: pp. 15-20)? For example, the original Greek word used in the biblical text was inclusive: äv $\theta \rho \omega \pi$ rochuman being, yet it is translated in many English translations as man ( $\mathrm{man}$ is the male and it became a term to represent also women). This needs an anthropological, philosophical and theological inquiry to see how the word äv $\theta \rho \omega \pi \circ$ in which both sexes are originally included, came to mean "man" in English biblical translations, where the term men represents also women. Feminists do not want to be represented, but to be included as in the original Greek text. Otherwise the anthropology of women becomes in English translations androcentric. The problem of non inclusive interpretation becomes

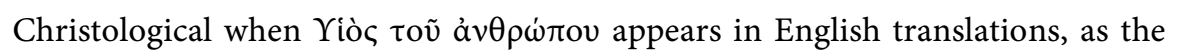
Son of Man. ${ }^{5}$

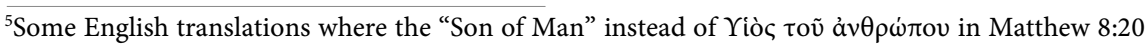
appears are: ESV, KJG, KJV, MRD, NIV etc. 


\section{The Dualism between Humanity and Nature}

If we free ourselves from the enclosure of old world models to experience the lost realization of ourselves as existing within the cosmic life processes, our words will be inadequate to express our existence in the world. Our "being" is never an isolated system. We become aware of our self and its enlargement through connectivity, just as the cosmos is interconnected at the inner being level of its members. We experience the tendency "to extend one's own self" (Clarke, 2002: pp. 113, 142, 69, 155). "I" and any cosmic being, depend on the entire cosmos in space/time. The bounds of a living being are open, a surface of metamorphicexchange. A breathing being draws substance from the soil and the plants. Beings contribute to the air, to earth, and to nourishment of insects and trees spreading out the self and breathing the world into it. The plants, receive sunenergy, and photosynthesize to sustain life. Cosmic phenomena influence all earthly and cosmic beings. Nothing is itself without all else; the cosmos advances into a differentiated web of relationships (Swimme \& Berry, 1992: p. 77).

Christianity shaped both by Hebraic and Greek traditions, was struggling against Gnosticism to regain the view of nature as God's good creation. Irenaeus was combating Gnostic anti cosmism, while synthesizing Hebraic creationism (Irenaeus Bishop of Lyon, 2003: pp. 49-56). In some cases Christianity, influenced by Neoplatonism, imbibed the platonic eschatology of the soul's escape from the body returning to a world outside the earth. Though the Hebrew idea of resurrection was retained, this idea allowed the soul towards the immortal light, but not of the body. The body is seen in its physical processes as the essence of sin, as mortal corruptibility. Part of ascetic Christianity imagined women as freed from subordination, if they rejected their sexuality and reproductive role. But the dark side of medieval Christianity saw nature as possessed by demonic powers that draw humans down to sin through sexual temptation. ${ }^{6}$

The biblical God, as outside the physical dimension of bodies, is an idea that fused with Greek philosophical dualism of spirit/matter became the identity of the Western ruling-male class. By breaking open the conceptual cage of dualisms, feminist theology offers critical grounding for ecofeminist theology to face the dualism amid human and non-human creation (Plumwood, 1993: pp. 55, $190,194)$. Feminizing nature and naturalizing of women are aspects of domination; feminist theology's analysis shows many forms as seeing the other as inferior and separate, a substructure offering an analytical tool. ${ }^{7}$

The prevailing mechanistic thought in the past that still remains in many even Christian communities as such, was that the domination of nature and women and the religious justification for exploiting nature were linked. Conquering nature was seen through the metaphor of conquering women. The rise of a global economy exploiting human and natural resources (Merchant, 1980) is linked

${ }^{6}$ Summers Montague, (ed.), Malleus Maleficarum (London: J. Rodker, 1928), cited in: Radford Ruether, "Ecofeminism Symbolic and Social Connections of the Oppression of Women and the Domination of Nature”, pp. 13-20.

${ }^{7}$ Val Plumwood, “Androcentrism and Anthropocentrism: Parallels and Politics' The Twenty Second Annual Richard Baker Philosophy Colloquium on Ecofeminist perspectives", (University of Dayton, OH, 30 March 1995):12-13, cited in Eaton, Introducing Ecofeminist Theologies, pp. 59. 
with the modern, scientific, mechanistic worldview, based on the ideology of control. Modern patriarchy can be linked with the slave trade, the colonial economies, the persecution of women-witches, the emergence of science/technology, and its mastery over nature (Mies, 1986). During the scientific revolution in the seventeenth and eighteenth centuries, natural science lost out to a dualism of transcendent intellect and dead matter. Nature became dead matter moving according to mathematical laws. Dead nature could be expropriated and reconstructed to augment its wealth and power. In the West, applying science to technological control over nature followed colonialism (Ruether, 1993: pp. 19-20).

\section{Epilogue}

Blame has been laid against patriarchal religion. A new start must deconstruct the women/nature connection, and include both women and men. Restructuring human personality as ecological persons is needed, as is rethinking the hierarchical philosophy of nature on which Christianity was based. A Christian ecofeminist creation-theology calls for a rethinking of all cosmic, earthly, and cultural theological reference points. The link between justice for women and the sustaining of life opens up new priorities for Christian communities. Our world experiencing takes place within our alienated selves, within the realities of the eco-crisis, the global economic system, and the reduction of people and all life forms to non-beings. Biblical sources can inspire us: the tree of knowledge of good and evil is also the tree of life (Grey, 2004: pp. 157-162).

The patristic use of Christological perichoresis shows how in bringing together God and humanity, God and Nature that is Creator and creation in the one person of incarnated Christ we can understand the perichoresis of the two natures of Christ: We can see everything in heaven and on earth united in Christ incarnated. Christological perichoresis supports the idea that the whole creation is included in God's recreated cosmos, in response to the redeeming power of Christ who became flesh and, entered the web of life as a creature. Trinitarian relationships bear an Christological message for intentional openness towards the "other". Thus I can consider ecofeminism from a Christian view, realizing Christ's "cosmic" role in the salvation of the entire cosmos. I make my case for an Christological perichoresis as an evolutionary step further in the direction of ecofeminist theology, which can be an original contribution which supports my ecofeminist Christian view. Christological perichoresis, as the divine form of contextualization, can enable us to follow Christ's steps to contextualize by taking our own contexts seriously. Human contextualization can only be a witness of divine contextualization. God is present in all things by virtue of their being created. If the actualization of the image of God in creation (Romans 1.20) depends upon humanity, the actualization of the image of God in humanity depends upon creation.

\section{References}

Antonio, E. (2002). Black Theology. In Rowland (Ed.), The Cambridge Companion to Liberation Theology. United Kingdom: Cambridge University Press. 
Chamlin, J. K. (1993). Psychology. In G. F. Howthorne, R. P. Martin, \& D. G. Reid (Eds.), Dictionary of Paul and His Letters. Leicester: InterVarsity Press.

Clarke, C. (2002). Living in Connection. Warminster: Creation Spirituality Books.

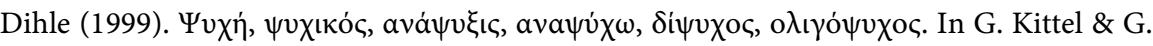
Friedrich (Eds.), Theological Dictionary of the New Testament (pp.611-612). Bromiley, G. W. Trans. Vol. IX, $\Phi-\Omega$.Grand Rapids: Eerdmans.

Eaton, H. (2005). Introducing Ecofeminist Theologies. New York: T \& T International.

Fiorenza, S. (2002) Bread Not Stone. Boston: Beacon Press.

Grey, M. (2004). Ecofeminism and Christian Theology. In L. Vischer (Ed.), Listening to Creation Groaning. Geneva: John Knox Series.

Gutierrez, G. (1999). The Task and Content of Liberation Theology. Condor, J. Trans. In Rowland (Ed.), The Cambridge Companion to Liberation Theology . Cambridge: Cambridge. https://doi.org/10.1017/ccol0521461448.002

Habel, N. (2000). Guiding Ecojustice Principles. In N. C. Habel (Ed.), The Earth Story in Genesis. Sheffield: Sheffield Academic Press.

Irenaeus Bishop of Lyon (2003). Against heresies. In C. Keller (Ed.), Face of the Deep. London: Routledge.

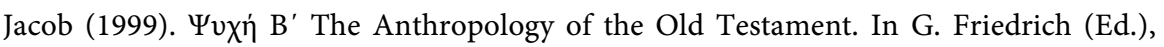
Theological Dictionary of the New Testament. Grand Rapids: WM. B. Eerdmans Publishing Company.

Lerner, G. (1988). The Creation of Patriarchy. New York: Oxford University Press.

Merchant, C. (1980). The Death of Nature Women, Ecology and the Scientific Revolution. New York: HarperSanFrancisco.

Mies, M. (1986). Patriarchy and Accumulation on a World Scale: Women in the International Division of Labour. London: Zed Books.

Mies, M. (1993). Women have no Fatherland. In: M. Mies, \& V. Shiva (Eds.), Ecofeminism. London: Red Books.

Miller, P. (1993). Whatever Happened to the Soul? Theology Today, 50/4.

Moltmann, J. (1985). The Gifford Lectures 1984-5, God in Creation: An Ecological Doctrine of Creation. London: SCM Press.

Montague, S. (Ed.) (1928). Malleus Maleficarum. London: J. Rodker, cited in: Ruether, R. R. "Ecofeminism Symbolic and Social Connections of the Oppression of Women and the Domination of Nature".

Plumwood, V. (1993). Feminism and Mastery of Nature. New York: Routledge.

Plumwood, V. (1995). Androcentrism and Anthropocentrism: Parallels and Politics. The Twenty Second Annual Richard Baker Philosophy Colloquium on Ecofeminist Perspectives, University of Dayton, $\mathrm{OH}, 12-13$. In Eaton, Introducing Ecofeminist Theologies.

Rowland, K. C. (Ed.) (1999). Preface. In The Cambridge Companion to Liberation Theology. Cambridge: Cambridge University Press. https://doi.org/10.1017/CCOL0521461448

Ruether, R. R. (1993). Ecofeminism Symbolic and Social Connections of the Oppression of Women and the Domination of Nature. In C. J. Adams (Ed.), Ecofeminism and the Sacred. New York: Continuum.

Sahinidou, I. (2014). Hope for the Suffering Ecosystems of Our Planet, Contextualization of Christological Perichoresis for the Ecological Crisis. Frankfurt: Peter Lang. https://doi.org/10.3726/978-3-653-04213-9 
Swimme, B., \& Berry, T. (1992). The Universe Story. New York: HarperCollins.

Warren, K. J. (1993). A Feminist Philosophical Perspective on Ecofeminist Spiritualities. In C. J. Adams (Ed.), Ecofeminism and the Sacred. New York: Continuum.

X

http://human-nature.com/free-associations/engel1.html

Submit or recommend next manuscript to SCIRP and we will provide best service for you:

Accepting pre-submission inquiries through Email, Facebook, LinkedIn, Twitter, etc. A wide selection of journals (inclusive of 9 subjects, more than 200 journals) Providing 24-hour high-quality service User-friendly online submission system Fair and swift peer-review system Efficient typesetting and proofreading procedure Display of the result of downloads and visits, as well as the number of cited articles Maximum dissemination of your research work

Submit your manuscript at: http://papersubmission.scirp.org/

Or contact ojpp@scirp.org 